\title{
Evaluation of Different Drainage Systems and Sowing Dates for Improving Wheat Productivity on Vertisols of Central Highlands of Ethiopia
}

\author{
Sakatu Hunduma Legesse Admassu, \\ Ethiopian Institute of Agricultural Research, Holeta Agricultural Research Center, P.O. Box 2003, \\ Addis Ababa, Ethiopia
}

\begin{abstract}
Water logging is a challenge to crop productivity under the rain fed system on Vertisols of central highlands of Ethiopia. Using appropriate drainage system and manipulating planting dates can reduce the effect of water logging and improve productivity of Vertisols of the area. The current field experiment was conducted to evaluate four different drainage systems ( Dry planting, Ridge \&Furrow (RF), Broad Bed Maker( BBM) and Flat bed) and five sowing dates (Mid may, Early June, Mid-late June, Mid July and Late August ) in improving productivity of wheat crop on vertisol of central highlands of Ethiopia under rain fed condition during the main cropping season. The treatments of the experiment were the systematic combination of four drainage systems and five planting dates. The experiment was conducted at three locations (Ginchi on station, Sheno and Sodo dache on farm) on Vertisols of central highlands of Ethiopia. Analysis of variance indicated that some of wheat Yield related parameters (Plant height, spike length, biomass yield and grain yield ) tasted were significantly $(\mathrm{p}<0.05)$ affected by different drainage systems and sowing dates. According to this research trial, Out of seven treatments tasted $\mathrm{T}_{2}$ (Early June + Dry plating) provide the highest grain yield $2214.7 \mathrm{Kg} / \mathrm{ha}, 2230 \mathrm{~kg} / \mathrm{ha}$ and $8253 \mathrm{~kg} / \mathrm{ha}$ was recorded at Ginchi, sodo dache and sheno sites respectively. As vertisols in Ethiopia exist in different agro-climatic conditions in the country and show a considerable variability the research should be repeated and be supported with the long term local weather and soil data in order to determine drainage systems and sowing dates for a specific locations of vertisol areas.
\end{abstract}

Keywords: Vertislol, Drainage system, planting date, Yield, Wheat

DOI: $10.7176 / \mathrm{JNSR} / 11-19-05$

Publication date:October $31^{\text {st }} 2020$

\section{Introduction}

Agriculture in Ethiopia is dominated by low productive rain fed farming. The annual grain production, which averages 7 million tonnes, is too low to support national food demands (Eyasu, 2005). In Ethiopia, Vertisols account for 12.6 million hectares, of which about 7.6 million ha found in the highlands and are generally waterlogged due to abundant rainfall during the growing period. These soils are generally hard when dry and sticky when wet, a very low infiltration rate when the surface is sealed, very low saturated hydraulic conductivity and compaction as a result of swelling, and therefore presents serious limitations to their use.

Crop production on the Ethiopian Vertisols is limited because of impeded drainage, difficulty of land preparation, soil erosion and low soil fertility (Tekalign et al., 1988; Haque, 1992). However, these soils have considerable productive potential, but they are usually underutilized in the traditional production system (Paulos el al., 2001). Crop productivity on Vertisols can be increased through early planting and improved surface drainage. Appropriate cropping systems are required for efficient use of the whole growing season.

Several studies conducted in various agro-ecologies have shown that surface drainage allows early sowing, enabling the full utilization of the potentially available growing period (El-Swaify et al., 1985; Abate Tedla et al., 1988; Astatke and Kelemu, 1993). Early planting increases the beneficial depletion of water while suppressing losses due to evaporation and runoff. Besides, the early-established surface cover reduces soil erosion (Teklu et al., 2004, 2006), leading to ecological sustainability. A surface drainage method, known as broad bed and furrows (BBF) constructed by a broad bed maker (BBM), which was developed at the International Crops Research Institute for the Semi-Arid Tropics (ICRISAT) in India (El-Swaify et al., 1985) and later modified to fit the smallholder system in Ethiopia (Astatke and Kelemu, 1993), has been popularized in the major Vertisol areas of the country. Among the advantages of BBF over the traditional ridge and furrows (RF) is the lower furrow to bed ratio, which provides a higher effective growing area per unit of plot. Despite its economic and ecological advantages (Teklu et al., 2006), the adoption rate of BBF by farmers in some places did not meet expectations, owing to socio-economic, cultural and technical constraints (Teklu, 2005). One important technical difficulty frequently mentioned by farmers was the timing of BBF preparation. Soil moisture content close to field capacity at planting is a prerequisite for BBF preparation, but this condition often lasts only for a few days. Therefore, while the refinement of BBM to overcome some of the drawbacks continues, seeking simpler and cheaper alternatives, which are easy for farmers to adopt to unlock the potential productivity of Vertisols, has become equally important. 
Hence, achieving sustainable and improved management of Vertisols has been a major challenge for Ethiopian farmers for many years, the current study was planned to evaluate effect different drainage systems and sowing dates in improving the productivity of wheat crop on vertisol in central highlands of Ethiopia.

\section{Materials and method}

The current experiment was implemented at three locations (Ginchi sub- station, Sodo and Sheno on farm) on vertisol during the main cropping season in 2014. The treatments of the experiment were six planting dates and four drainage systems where they are combined systematically. Seven treatments were arranged in Randomized Completed Block Design with four replications. Treatment combinations were: $\mathrm{T}_{1}=$ Mid May + local plow (dry planting), $\mathrm{T}_{2}=$ Early June + local plow (dry planting), $\mathrm{T}_{3}=$ Mid - late June + Ridge \&Furrow $(\mathrm{RF}), \mathrm{T}_{4}=$ Early July + Broad Bed Maker $(B B M), T_{5}=$ Early July + RF, $T_{6}=$ Mid July + RF and $T_{7}=$ Late August + flat planting with residual moisture. The plot size of each treatment was $5 \mathrm{~m}$ x $5 \mathrm{~m}$. A short duration maturing improved wheat variety was used as a taste crop. All recommended cultural practices were adopted for management of the experiment.

\section{Statistical analysis}

The data were subjected to analysis of variance using the procedure of the of SAS statistical package version 9.0 (SAS Institute, 2004). Means for the main effects were compared using the means statement with least significant difference (LSD) test at the 5\% level.

\section{Results and Discussions}

Seven treatments containing different drainage systems and sowing dates were tasted to evaluate response of yield and yield related parameters of wheat crop on three sites on vertisol in the central highlands of Ethiopia. Since the trial was conducted at different locations under rain fed system due to the fluctuation of weather specially starting time of rain there were zero values recorded in the data and as a result the coefficient of variance $(\mathrm{CV} \%)$ becomes high in some parameters tasted.

\section{Yield and yield Components Plant height}

One of the wheat growth parameter tasted to evaluate the drainage systems and sowing dates was plant height. At all sites plant height was significantly affected by drainage systems and sowing dates (Table 1, Table 2 and Table 3). At Ginchi site the highest plant height $(84.37 \mathrm{~cm})$ was recorded by $\mathrm{T}_{2}$ (Early June + Dry plating) in which the lowest plant height $(61.4 \mathrm{~cm})$ was recorded by $\mathrm{T}_{7}$ (Late August + Flat bed) (Table 1). At sodo dache site the highest plant height $(77.88 \mathrm{~cm})$ was recorded by the use of $\mathrm{T}_{3}$ (Mid-late June + Ridge \&Furrow(RF)) but it was not significantly different from Plant height recorded by $\mathrm{T}_{2}$ and $\mathrm{T}_{4}$ (Table 2). At sheno site the highest plant height $(92.75 \mathrm{~cm})$ was recorded by the use of $\mathrm{T}_{3}$ (Mid-late June + Ridge \&Furrow $(\mathrm{RF})$ ) but it was not significantly different from Plant height recorded by $\mathrm{T}_{2}, \mathrm{~T}_{4}$ and $\mathrm{T}_{5}$ (Table 3 ).

Table 1: Effect of drainage systems and sowing dates on yield of wheat on vertisol at Ginchi sub- station in the main cropping season of the year 2014.

\begin{tabular}{|c|c|c|c|c|c|c|}
\hline \multirow[t]{2}{*}{ Treat.No. } & \multicolumn{2}{|c|}{ Treatments } & \multirow{2}{*}{$\begin{array}{l}\text { Plant height } \\
\text { (cm) }\end{array}$} & \multirow{2}{*}{$\begin{array}{l}\text { Spike } \\
\text { length } \\
\text { (cm) }\end{array}$} & \multirow{2}{*}{$\begin{array}{l}\text { Biomass yield } \\
\text { (kg/ha) }\end{array}$} & \multirow{2}{*}{$\begin{array}{l}\text { Grain yield } \\
(\mathrm{kg} / \mathrm{ha})\end{array}$} \\
\hline & $\begin{array}{l}\text { Sowing } \\
\text { dates }\end{array}$ & Drainage systems & & & & \\
\hline 1 & Mid May & Dry planting & $64.825 \mathrm{e}$ & $6.925 \mathrm{~d}$ & $5083 a$ & $259.8 \mathrm{c}$ \\
\hline 2 & Early June & Dry planting & $84.375 \mathrm{a}$ & $11.9 \mathrm{a}$ & $7333 a$ & $2214.7 \mathrm{a}$ \\
\hline 3 & $\begin{array}{l}\text { Mid-late } \\
\text { June }\end{array}$ & $\begin{array}{l}\text { Ridge } \\
\text { \&Furrow(RF) }\end{array}$ & $80.8 \mathrm{ab}$ & $8.225 \mathrm{c}$ & $4833 a$ & $249.5 c$ \\
\hline 4 & Early July & BBM & $75.1 \mathrm{bc}$ & $8.3 \mathrm{c}$ & $9833 a$ & $1101.8 b$ \\
\hline 5 & Early July & $\begin{array}{l}\text { Ridge } \\
\text { \&Furrow(RF) }\end{array}$ & $66.875 \mathrm{de}$ & $11.825 \mathrm{a}$ & $7667 a$ & $344.4 \mathrm{c}$ \\
\hline 6 & Mid July & $\begin{array}{l}\text { Ridge } \\
\text { \&Furrow(RF) }\end{array}$ & $71.75 \mathrm{~cd}$ & $9.575 \mathrm{~b}$ & $5583 a$ & $672.2 b c$ \\
\hline 7 & $\begin{array}{l}\text { Late } \\
\text { August }\end{array}$ & $\begin{array}{l}\text { Flat bed(residual } \\
\text { moisture) }\end{array}$ & $61.425 \mathrm{e}$ & $8 \mathrm{~cd}$ & $8917 a$ & $265.5 c$ \\
\hline & & Sig. & $* *$ & $* *$ & ns & $* *$ \\
\hline & & CV( $\%)$ & 5.47 & 8.9 & 53.22 & 60 \\
\hline
\end{tabular}

Notes. Significant at $* \mathrm{P} \leq 0.05, * * \mathrm{P} \leq 0.01, * * * \mathrm{P} \leq 0.001 ; \mathrm{ns}$, not significant; $\mathrm{CV}$, coefficient of variation 


\section{Spike length}

Analysis of the data of the three locations indicated that spike length was significantly affected by different drainage systems and sowing dates (Table 1, Table 2 and Table 3). At 'Ginchi' site the highest spike length (11.9 $\mathrm{cm}$ ) was recorded by the use of $\mathrm{T}_{2}$ (Early June + Dry plating) but it was statistically not different from the spike length $(11.8 \mathrm{~cm})$ recorded by $\mathrm{T}_{5}$ (Early July + Ridge \&Furrow (RF)) (Table 1). Both at sodo dache and sheno sites spike length was not significantly different for all treatments except $\mathrm{T}_{7}$ (Late August + Flat bed). The lowest spike length was recorded by the use of $\mathrm{T}_{7}$ (Table 2 and Table 3 ).

Table 2: Effect of drainage systems and sowing date on yield of wheat on vertisol at Sodo dachi on farm in the main cropping season of the year 2014.

\begin{tabular}{|c|c|c|c|c|c|c|}
\hline \multirow{2}{*}{$\begin{array}{l}\text { Treat. } \\
\text { No. }\end{array}$} & \multicolumn{2}{|c|}{$\begin{array}{l}\text { Treatments } \\
\end{array}$} & \multirow{2}{*}{$\begin{array}{l}\text { Plant } \\
\text { height } \\
\text { (cm) }\end{array}$} & \multirow{2}{*}{$\begin{array}{l}\text { Spike } \\
\text { length } \\
\text { (cm) }\end{array}$} & \multirow{2}{*}{$\begin{array}{l}\text { Biomass } \\
\text { yield (kg/ha) }\end{array}$} & \multirow{2}{*}{$\begin{array}{l}\text { Grain yield } \\
(\mathrm{kg} / \mathrm{ha})\end{array}$} \\
\hline & $\begin{array}{l}\text { Sowing } \\
\text { dates }\end{array}$ & Drainage systems & & & & \\
\hline 1 & Mid May & Dry planting & $47.55 \mathrm{~b}$ & $6.6 \mathrm{a}$ & $0.0 \mathrm{~b}$ & $0.0 \mathrm{~d}$ \\
\hline 2 & Early June & Dry planting & $75.65 a$ & $7.1 \mathrm{a}$ & $5450 \mathrm{a}$ & $2230.1 \mathrm{a}$ \\
\hline 3 & $\begin{array}{l}\text { Mid-late } \\
\text { June }\end{array}$ & Ridge \&Furrow(RF) & $77.88 \mathrm{a}$ & $7.2 \mathrm{a}$ & $4010 \mathrm{a}$ & $1378.7 \mathrm{bc}$ \\
\hline 4 & Early July & $\mathrm{BBM}$ & $77.13 \mathrm{a}$ & $6.7 \mathrm{a}$ & $5490 \mathrm{a}$ & $1995.8 \mathrm{ab}$ \\
\hline 5 & Early July & Ridge \&Furrow(RF) & $74 a$ & $7.0 \mathrm{a}$ & $5890 \mathrm{a}$ & $1808.3 \mathrm{ab}$ \\
\hline 6 & Mid July & Ridge \&Furrow(RF) & $70.38 \mathrm{ab}$ & $6.5 \mathrm{a}$ & $5270 \mathrm{a}$ & $1263.1 \mathrm{bc}$ \\
\hline 7 & Late August & $\begin{array}{ll}\begin{array}{l}\text { Flat } \\
\text { moisture) }\end{array} & \text { bed(residual } \\
\end{array}$ & $13.98 \mathrm{c}$ & $0.0 \mathrm{~b}$ & $4130 \mathrm{a}$ & $803.1 \mathrm{c}$ \\
\hline & & Sig. & $* *$ & $* * *$ & $* * *$ & $* * *$ \\
\hline & & CV(\%) & 28 & 20 & 32.7 & 39.4 \\
\hline
\end{tabular}

Notes. Significant at $* \mathrm{P} \leq 0.05, * * \mathrm{P} \leq 0.01, * * * \mathrm{P} \leq 0.001 ; \mathrm{ns}$, not significant; $\mathrm{CV}$, coefficient of variation

\section{Biomass yield}

Analysis of variance indicated that effect of drainage systems and sowing dates is not significantly affect biomass of the wheat crop at Ginchi site (Table 1). At sheno site biomass was significantly affected by different drainage systems and sowing dates in which the highest biomass yield ( $11013 \mathrm{~kg} / \mathrm{ha}$ ) was recorded by using $\mathrm{T}_{2}$ (Early June + Dry plating)(Table 3). At sodo dache site the effect of different drainage systems and sowing dates was not significant for all treatments except $\mathrm{T}_{1}$ (Mid may + Dry planting ) in which the lowest biomass yield was recorded at the area (Table 2).

Table 3: Effect of drainage systems and sowing date on yield of wheat on vertisol at Sheno on farm in the main cropping season of the year 2014.

\begin{tabular}{|l|l|l|l|l|l|l|}
\hline \multirow{2}{*}{$\begin{array}{l}\text { Treat. } \\
\text { No. }\end{array}$} & $\begin{array}{l}\text { Sowing } \\
\text { dates }\end{array}$ & Drainage systems & $\begin{array}{l}\text { Plant } \\
\text { height } \\
(\mathrm{cm})\end{array}$ & $\begin{array}{l}\text { Spike length } \\
(\mathrm{cm})\end{array}$ & $\begin{array}{l}\text { Biomass yield } \\
(\mathrm{kg} / \mathrm{ha})\end{array}$ & $\begin{array}{l}\text { Grain } \\
(\mathrm{kg} / \mathrm{ha})\end{array}$ \\
\hline 1 & Mid May & Dry planting & $85.7 \mathrm{~b}$ & $8.95 \mathrm{a}$ & $6630 \mathrm{ab}$ & $4300 \mathrm{ab}$ \\
\hline 2 & Early June & Dry planting & $91.81 \mathrm{a}$ & $8.55 \mathrm{a}$ & $11013 \mathrm{a}$ & $8253 \mathrm{a}$ \\
\hline 3 & $\begin{array}{l}\text { Mid-late } \\
\text { June }\end{array}$ & Ridge \&Furrow(RF) & $92.75 \mathrm{a}$ & $7.22 \mathrm{a}$ & $6392 \mathrm{ab}$ & $3732 \mathrm{bc}$ \\
\hline 4 & Early July & BBM & $90.42 \mathrm{a}$ & $7.15 \mathrm{a}$ & $7333 \mathrm{ab}$ & $3013 \mathrm{bc}$ \\
\hline 5 & Early July & Ridge \&Furrow(RF) & $90.3 \mathrm{a}$ & $7.07 \mathrm{a}$ & $5537 \mathrm{~b}$ & $2537 \mathrm{bc}$ \\
\hline 6 & Mid July & Ridge \&Furrow(RF) & $82.7 \mathrm{~b}$ & $6.77 \mathrm{ab}$ & $4488 \mathrm{bc}$ & $1968 \mathrm{bc}$ \\
\hline 7 & $\begin{array}{l}\text { Late } \\
\text { August }\end{array}$ & $\begin{array}{l}\text { Flat bed(residual } \\
\text { moisture) }\end{array}$ & $0.0 \mathrm{c}$ & $1.9 \mathrm{~b}$ & $0.0 \mathrm{c}$ & $0.0 \mathrm{c}$ \\
\hline & Sig. & $* * *$ & $\mathrm{~ns}$ & $* * *$ & $* * *$ \\
\cline { 2 - 7 } & CV( \%) & 3.9 & 22.3 & 54.2 & 85.06 \\
\hline
\end{tabular}

Notes. Significant at $* \mathrm{P} \leq 0.05, * * \mathrm{P} \leq 0.01, * * * \mathrm{P} \leq 0.001$; ns, not significant; $\mathrm{CV}$, coefficient of variation

\section{Grain yield}

It is known that, grain yield is very limiting yield parameter in testing the effect of all management practices in agronomic research trials. Analysis of the data of the three locations (Ginchi, Sodo dache and Sheno) indicated that grain yield was significantly affected by different drainage systems and sowing dates (Table 1, Table 2 and Table 3). Analysis of the grain yield data of the three locations indicated that, the relatively highest grain yield $2214.7 \mathrm{Kg} / \mathrm{ha}, 2230 \mathrm{~kg} / \mathrm{ha}$ and $8253 \mathrm{~kg} / \mathrm{ha}$ was recorded at Ginchi, Sodo dache and Sheno sites respectively using $\mathrm{T}_{2}$ (Early June + Dry plating)(Table1, Table $2 \&$ Table 3 ). 
Vertisols in Ethiopia exist in different agro-climatic conditions and show a considerable variability, which should be fully understood when developing technologies to improve their performance. Out of seven treatments tasted $\mathrm{T}_{2}$ (Early June + Dry plating) provide the highest grain yield at all study sites (Fig 1). But each study site respond differently to the treatments tasted due to considerable variability of the sites. based on the current study Sheno site recorded the highest grain yield followed by Sodo dache and Ginchi site recorded relatively lowest grain yield(Fig 1).

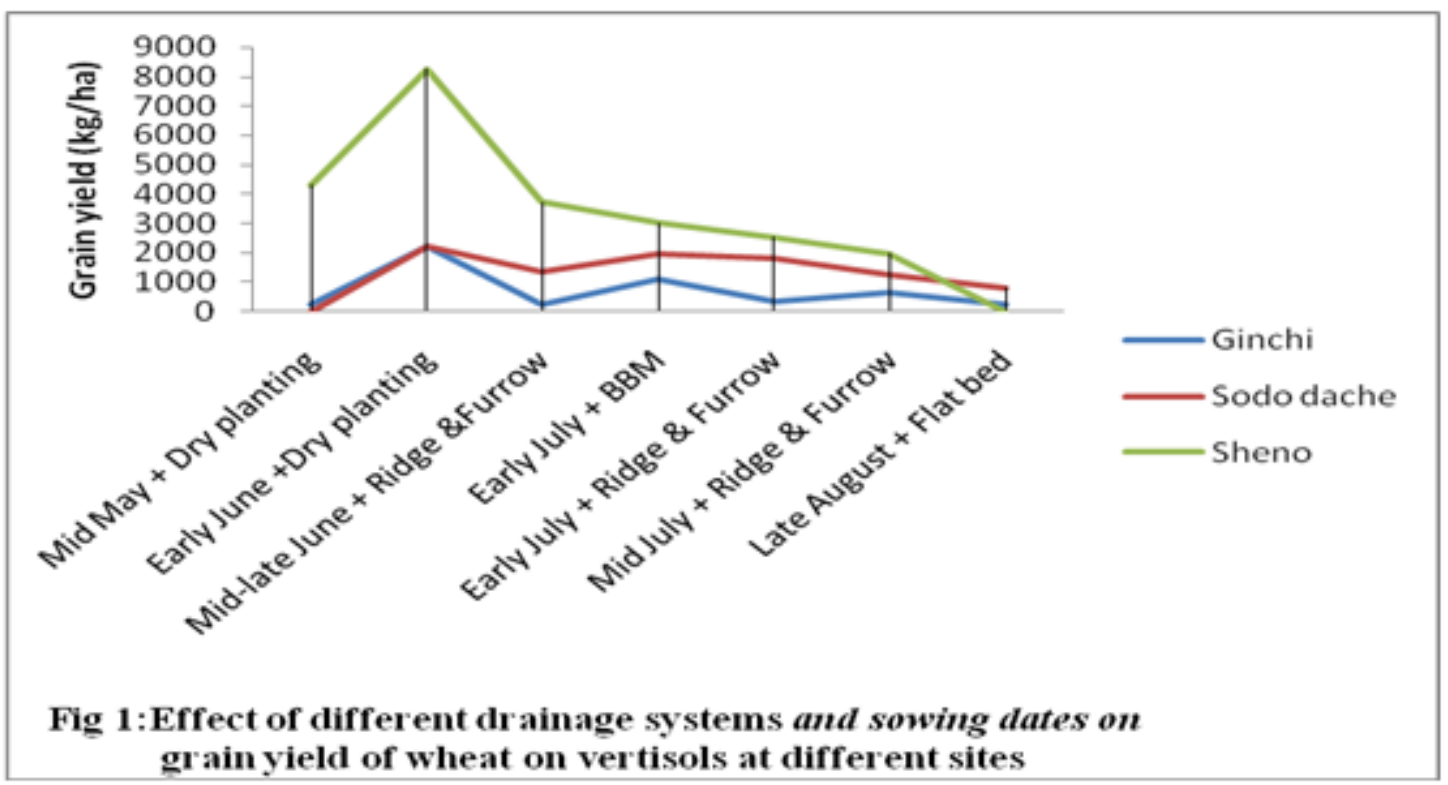

\section{Conclusions}

The physical management of Vertisols depends on the climatic zone, relief, and type of Vertisol. Crop productivity on Vertisols can be increased through early planting and improved surface drainage. The current field experiment was conducted to evaluate four different drainage systems ( Dry planting, Ridge \&Furrow (RF), Broad Bed Maker( BBM) and Flat bed) and five sowing dates (Mid may, Early June, Mid-late June, Mid July and Late August ) in improving productivity of wheat crop on vertisol of central highlands of Ethiopia under rain fed condition during the main cropping season 2014. According to this research trial, Out of seven treatments tasted $\mathrm{T}_{2}$ (Early June + Dry plating) provide the highest grain yield $(2214.7 \mathrm{Kg} / \mathrm{ha}, 2230 \mathrm{~kg} / \mathrm{ha}$ and $8253 \mathrm{~kg} / \mathrm{ha}$ was recorded at Ginchi, Sodo dache and Sheno sites respectively). In conclusion, as vertisols in Ethiopia exist in different agro-climatic conditions in the country and show a considerable variability the research should be repeated and be supported with the long term weather and soil data in order to determine drainage systems and sowing dates for a specific locations of vertisol areas.

\section{References}

Abate Tedla, Juts SC, Getenet G. 1988. Performance of improved bread wheat varieties on some Ethiopian highlands Vertisols under enhanced surface drainage. Paper presented at the First Annual Conference of the Crop Science Society of Ethiopia, Addis Ababa, 8-9 February; 14 pp.

Astatke A, Kelemu F. 1993. Modifying the traditional plough maresha for better management of Vertisols. In Improved Management of Vertisols for Sustainable Crop-Livestock Production in the Ethiopian Highlands, Mamo T, Astatke A, Srivastava KL, Dibabe YA (eds). Synthesis Report 1986- 1992. Technical Committee of the Joint Vertisol Project: Addis Ababa, Ethiopia.

El-Swaify SA, Pathak P, Rego TJ, Singh S. 1985. Soil management for optimised productivity under rained conditions in the semi-arid tropics. In Advances in Soil Science, vol. 1, Stewart BA (ed.). Springer-Verlag: New York; 1-64.

Eyasu, Y., 2005. Development and management of irrigated lands in Tigray, Ethio- pia. Ph.D. Thesis. Department of Water Engineering, UNESCO-IHE Institute for Water Education, Delft, The Netherlands.

Haque, L. 1992. Use of legume biological nitrogen fixation in crop and livestock production systems. In: Mulongoy K, Gueye M and Spencer D S C. (eds), Biological nitrogen fixation and sustainability of tropical agriculture. A Wiley Saye Co-publication. pp. 423-437.

Paulos, D., Asgelil, D., Asfaw, Z., Gezahegn, A., and Abebe, K. 2001. Advances in Vertisols Management in the Ethiopian Highlands. Proceedings of the International Symposium on Vertisols Management, 28 November to 1 December 2000, Ethiopian Agricultural Research Organization, Addis Ababa, Ethiopia. 
SAS Institute (2004). SAS/STAT guide for personnel computers, version 9, edition. Cary, NC: SAS Institute Inc. Tekalign, M. and Haque, I.1988. Potassium status of some Ethiopian soils. East African Agriculture and Forestry Journal 53/3:123-130.

Teklu E, Assefa G, Stahr K. 2004. Land preparation methods efficiency on the highland Vertisols of Ethiopia. Irrigation and Drainage 53: 69-75. Teklu E, Fisseha I, Stahr K. 2006. Tillage effects on sediment enrichment, soil quality, and crop productivity in Ethiopian Highlands. Australian Journal of Soil Research 44: 753-758.

Teklu E. 2005. Land preparation methods and soil quality of a Vertisol area in the Central Highlands of Ethiopia. Hohenheimer Bodenkundliche Hefte 73. PhD thesis, Institute of Soil Science and Land Evaluation, University of Hohenheim, Germany. 